\title{
INCLUSIVE POLICIES AND THE PERILS OF DISSONANCE: A CASE STUDY OF AN INTERNATIONAL BACCALAUREATE PUBLIC SCHOOL IN ECUADOR
}

Tiago Bittencourt ${ }^{1}$

University of Minnesota, USA

\begin{abstract}
In 2006, the Ecuadorian Ministry of Education signed an agreement which sought to gradually introduce the International Baccalaureate's Diploma Programme into as many of the country's 1400 publicly funded secondary schools as possible. The initiative was part of a concerted effort aimed at addressing pervasive forms of inequality, argued to be colonially produced and exacerbated by recent neoliberal policies. Drawing on 5 months of ethnographic work in a low-income public school, this paper examines the effects the Ministry of Education's agreement has on a school's social cohesion. Findings showcase how the introduction of the Diploma Programme has inadvertently led to a dichotomized school, creating tensions between students and amongst the teaching staff. Furthermore, it has stigmatized students who either do not apply or are not accepted into the program. Based on these findings, I argue how a nation-wide education policy underlined by a logic of inclusion may create new and unanticipated micro-forms of exclusion at the school level. Consistent with the ongoing literature on inclusion, findings from this study emphasize the need for inclusion to be constituted as an ongoing process, one that demands consistent reevaluation and adaptation.
\end{abstract}

Keywords: Inclusion, International Baccalaureate, Social Reproduction, Ecuador, Education Policy, School Culture

From 1996 to 2005, Ecuador experienced a decade long political and financial crisis which saw seven presidents, three of which were toppled due to civil unrest. In 2006 Rafael Correa, a U.S trained economist and former university professor, campaigned under an antiestablishment platform promising a "sharp rupture from the prevailing political economic

\footnotetext{
${ }^{1}$ Correspondence: Department of Organizational Leadership and Policy Development, University of Minnesota, 178 Pillsbury Dr. SE, Minneapolis, MN 55455, USA; Email: bitte024@umn.edu
} 
system characterized by poverty, corruption and mismanagement” (Arsel, 2012, p. 154). His message resonated with a large segment of the Ecuadorian population who had become disillusioned with the existing political and economic order. Despite having limited political experience and running a campaign with little partisan support, Correa was elected with 56.7 percent of the popular vote.

Upon taking office, Correa and members of the country's constituent assembly proposed a new constitution aimed on addressing the material and representational forms of inequality that were argued as being colonially produced and exacerbated by recent neoliberal policies. Within the proposed constitution, education was articulated as being a priority for policy making and state investment. Undergirding this stance was a belief that systemic forms of inequality could only be addressed if the quality of the country's public schools were improved. Ecuadorian public schools were widely constituted as being severely underfunded, low performing, having high drop-out rates and an underprepared teaching staff (Albuja, 2016; Schneider, Estarellas, \& Bruns, 2017; Tamayo, 2014).

Through a referendum, the proposed constitution was approved in 2008 with overwhelming support. Since its approval, numerous educational initiatives have been implemented seeking to both improve the quality of the country's education system and provide additional educational experiences to public school students who were and still are predominantly low-income (Paladines, 2015). Initiatives included the creation of a national evaluation system, a proposed curriculum reform, increased teacher wages, and plans to boost government spending on education to $6 \%$ of GDP (Isch, 2011).

In addition, the newly elected government decided to expand an existing educational initiative known as the Inserción de Bachillerato Internacional en colegios fiscales del Ecuador. First signed in 2006, the initiative sought to introduce the International Baccalaureate's (IB) academically rigorous Diploma Programme (DP) into 18 public schools throughout the country. Although Correa was not yet president when the initiative was signed, it was under his administration that this small education policy became a wide-scale national movement with the intended goal of gradually reaching as many of the country's 1400 state secondary schools as possible (Barnett, Tokuhama-Espinos, Rivera, Montero, \& Palacios, 2013). Aligned with Correa's campaign promises, the initiative was premised on the conviction that existing patterns of social reproduction could be disrupted if public secondary school students had access to the educational experiences and credentials which in Ecuador were historically restricted to elite private institutions.

Enthusiasm for the agreement within the Ministry of Education compelled the promulgation of the Presidential Commitment no. 17270 that promised that 500 public secondary schools would either be accredited or in the process of receiving accreditation by the IB to implement the DP by the end of 2017 (Ministerio de Educación, 2017). While 200 public secondary schools are already fully authorized to implement the DP, not all students within those schools are eligible to enroll in the program. Each authorized school is expected to promote an application process, where only students with exemplary academic, disciplinary and leadership records are admitted (Espinosa, 2013).

Although the Ministry of Education has routinely framed the initiative as a success, the scaling of the DP has a number of detractors. This includes the country's highly politicized teachers' union who argue that the program imposes "foreign cultures and ideologies via education" (Resnik, 2014, p. 105). Furthermore, since not all public secondary school students have access to the program, the initiative is perceived as potentially creating new forms of inequality (Terán, 2015). Underscoring these critiques is a belief that the 
introduction of the DP into public secondary schools may reinforce the representational and material inequalities that the government has vehemently claimed to combat.

The premise of this study emerged as a response to these critiques. Specifically, I was interested in better understanding how this initiative was perceived and experienced not by policy makers and teacher organizations, but by the multiple stakeholders involved in its direct implementation. Drawing on data from a larger ethnographic study in a low-income public school, I was confronted with a growing level of concern from students, teachers and administrative staff that the introduction of the DP has significantly disrupted the school's social cohesion. This included prompting tensions between students and amongst the teaching staff, and stigmatizing students who either do not apply or are not accepted to the program.

Based on these findings, I argue how a nation-wide educational policy underlined by a logic of social inclusion may create new and unanticipated micro-forms of exclusion at the school level. Consistent with the recent trends in the literature on inclusion, findings from this study emphasize the need for the concept of inclusion to be constituted as an ongoing process, one that demands consistent reevaluation and adaptation. Before showcasing the findings of the study, I will provide a very brief overview of the IB and delineate how I am conceiving of the concept of social reproduction. Combined, these two sections are expected to provide a greater level of context to the paper and clarity as to how and why this policy initiative is intended on achieving its stated goal.

\section{The International Baccalaureate}

The IB is an educational organization founded in 1968 in Geneva, Switzerland. While increasingly present in nationally funded school systems, the organization's history is inextricably linked to the international school movement. Specifically, it emerged as a response to a growing demand by an internationally mobile student population for a diploma that had currency across multiple higher education systems, especially in Europe and North America. The result was the creation of an internationally-focused curriculum heavily influenced by the principles of experiential learning (Hill, 2002). The curriculum, which was originally offered in only English and French, was based on six core classes plus a compulsory artistic activity. To ensure both rigor and consistency, all classes included a standardized assessment prior to the completion of the program.

During its early years the IB catered to a small group of schools. Growing demand for a high school diploma that was recognized by different higher educational systems allowed the IB to rapidly grow especially in elite international schools. Tarc (2009) notes that the program's rather homogeneous student population led to questions regarding the legitimacy of its claim of promoting international forms of understanding. In response to these critiques, the IB underwent a deliberate effort to "shift away from its international school movement' base towards more involvement with national schooling and elite private schooling" (Bunnell, 2011, p. 170). These efforts led to a gradual shift in the program's student composition, especially when national school systems began turning to the IB as both a means of enhancing the quality of public education and of providing an educational alternative in teaching high-achieving children. Furthermore, many public schools turned to the IB as a form of distinction, a means of gaining cachet in their local markets and of providing their students with a form of positional advantage upon graduating (Doherty, 2013; Resnik, 2012; Yemini and Dvir, 2016).

With an ever-expanding number of schools incorporating the IB curriculum in to their practices, the organization began reconsidering both its role and purpose in education. 
Originally the IB was an educational program that was internationally focused and provided a diploma that was recognized amongst a diverse set of countries and institutions. As such its services were targeting students in the last two years of their high school education. In the 1990s the IB expanded its program to also include students in lower grade levels. In 1994, the Middle Years Program (MYP) was introduced and in 1997 the Primary Years Program (PYP). The previous IB curriculum focusing on the last two years of high school was rebranded as the DP (Tarc, 2009). Furthermore, the IB decided to include Spanish along with English and French as the official languages of both instruction and evaluation, allowing the organization to make headway into many new schools, especially in Latin America.

The expansion of the IB into state-funded schools does not, however, imply that program adoption barriers have been eliminated or even reduced. To become an IB school is still both costly ${ }^{2}$ and time consuming, requiring a rigorous application and authorization process that takes between two and three years. For example, to become authorized to provide the DP, "schools must demonstrate adherence to the IB's curricular, pedagogical, mission-based and ongoing professional development requirements" (Saavedra, Lavore, \& Georgina, 2016, p. 347). In addition, schools must show "that the infrastructure and skills are in place to deliver the programme to the IB's high standards" (IBO, 2016). Once approved, schools are regularly evaluated as a means of ensuring that the standards and practices of the IB are being maintained. The evaluation process takes place once every five years and includes a school self-study which aims on identifying the key elements required for continual improvement. The evaluation process also attempts to ensure that DP teachers are using IB approved curricular and pedagogical materials and undergoing ongoing professional development.

\section{Disrupting Existing Patterns of Social Reproduction}

The large investment required to become an authorized IB school can be prohibitive, especially for schools with a restricted discretionary budget. While costly, the Ecuadorian Ministry of Education views the signing of the Inserción de Bachillerato Internacional en colegios fiscales del Ecuador initiative as being an effective means of promoting long-lasting change to its public education system. Consistent with what Resnik (2012) refers to as "percolation", the belief is that the curricular and pedagogical approaches central to the DP model will inevitably seep into classrooms implementing the country's national curriculum. Meaning that while the DP will only be directly experienced by a limited group of students, the longterm benefits would be shared by all.

The need to instill change in the country's public schools is based on the conviction that Ecuador's education system has actively contributed to persistent forms of inequality. This operative conviction adheres to an important strand in the sociology of education commonly known as social reproduction theory. Broadly speaking, social reproduction refers to the manner which social inequality is transmitted from one generation to the next through existing structures and activities in society. Early understandings of social reproduction theory emphasized how schools promoted the principles and required social practices undergirding a ruling ideology to an unsuspecting cadre of youth (see Althusser, 2001). Bowles and Gintis (1976), for instance, used the "correspondence principle" to argue that

\footnotetext{
${ }^{2}$ Institutions in the Americas wishing to become an authorized provider of the IB diploma programme must pay a $\$ 4000$ application fee and a yearly fee of $\$ 9,500$ during the deliberation process. Once authorized as an official provider of IB diploma programme, the institution is required to pay a yearly fee of $\$ 11,650$ (IBO, 2017). Yearly fees do not include student registration and assessment costs.
} 
schools are internally organized to replicate the social relationships of work in a manner that coheres with the social backgrounds of their student body. Similarly, through a comparative study of four social distinct elementary schools Anyon (1980) found that while schools catering to an affluent student demographic promoted conceptual learning and student agency, working class schools stressed rote learning, the importance of respecting authority and an unquestioned abidance to school rules. Through these observations Anyon concluded that schooling does not always serve to rectify social stratification, but rather it socializes and prepares students to reproduce social class distinctions.

Although highly influential, early iterations of social reproduction such as that of Bowles and Gintis' were critiqued for departing from deterministic assumptions, which emphasize the capacity of schools to produce obedient citizens while ignoring how teachers and students may reinterpret, resist or even reject education's socializing effects. A more recent strand inspired by both Willis' (1977) and Bourdieu's $(1979,1987)$ watershed works has attempted to emphasize the ways individual actors interact and may even intentionally challenge normative sociocultural systems. The emphasis on the individual subsumes that in addition to economic imperatives, social reproduction should also examine the role of the cultural, symbolic and identity-forming implications of material inequality (Brantlinger, 2003; Calarco, 2018; Demerath, 2009; Foley, 1990; Friedman, 2013; Khan, 2011). Lareau's (2011) work exemplifies this approach. Her research interrogated the implications class-based forms of childrearing practices had on students' experience within social institutions such as schools. She concluded that the logics underlining middle-class approaches to childrearing were more at sync with institutional practices, affording middle-class students' significant advantages in comparison to their working-class and poor peers.

Chaney (1994) refers to this most recent approach as being the byproduct of a "cultural turn" to the analysis of social reproduction. Amongst other things, the "cultural turn" showcases the complexities of social reproduction and suggests that widening access to existing educational resources does not necessarily guarantee equality. It also highlights the need for idiographic research, which examines the new cultural configurations and understandings that emerge when a policy is contextualized in a specific locale. In the case of this study, it requires a closer look on how individuals directly implicated by the Inserción de Bachillerato Internacional en colegios fiscales del Ecuador initiative understand and respond to the policy's determinants. With this in mind, my research aimed on discerning the experiences and perspectives of students, teachers and administrative staff in an IB authorized public school.

\section{Methods}

This paper draws on a larger ethnographic study of a low-income public school offering the DP. Data collection took place over a five-month span in 2018, beginning in the month March and concluding in July. During the course of the study, I visited the school three times a week and utilized a series of data collection approaches including participant observations, formal and informal interviews, and the consultation of a wide variety of school documents and cultural artefacts such as transcribed assembly speeches, posters, class materials and news articles.

For the first two months of the study I conducted classroom observations, attended school events such as assemblies, and engaged in informal conversations with students, teachers and administrative staff. Consistent with Merriam and Tisdell's (2016) advice, these early data sources allowed me to learn "enough about a situation to formulate questions for subsequent interviews" (p. 111). While I continued observing classes through the extent of 
the study, in the month of May I began scheduling interviews with teachers, administrative staff and a select group of students. Interviews took place throughout the remainder of the study, concluding in the month of July. All interviews were semi-structured and employed questions that were open-ended, non-judgmental, and aimed at allowing "unanticipated statements and stories to emerge" (Charmaz, 2006, p. 26). In order to participate, all interviewees were required to provide documentation as required by the ethical review boards that approved this study. This included parental consent forms for underaged students. In total 15 formal interviews were conducted, each lasting anywhere between 30 and 80 minutes. Table 1 provides basic demographic information on each participant.

As is common in research that draws on ethnographic methods, my observations and interviews yielded a large amount of data. In an effort to engage with the data in a meaningful and productive way, I employed two different yet complimentary analytical approaches. The first step was inductive and drew on a grounded theory approach to analysis. This began with a process of data immersion which consisted of reading, reflecting, writing and re-reading my field notes and interview transcripts. Throughout this process I wrote a number of analytical memos which I used to identify emerging patterns in the data (Groenewald 2008).

Table 1:

Interviewee profiles (all pseudonyms)

\begin{tabular}{ccc}
\hline Pseudonym & Gender & Role \\
\hline Luis Romero & Male & Student \\
Andrea Macías & Female & Student \\
Julia Arroyo & Female & Student \\
Macarena Carrillo & Female & Student \\
Daniel Lopez & Male & Student \\
José Mosquera & Male & Student \\
Roberto Toaquiza & Male & Student \\
Maria Ullauri & Female & Student \\
Alejandra Moncayo & Male & Student \\
Paola Ycaza & Female & Student \\
Fernando Gonzalez & Male & Interim Dean \\
Eduardo Alarcon & Male & IB Coordinator \\
Francisco Reyes & Male & Teacher \\
Maria Espinosa & Female & Teacher \\
Juan José Sanchez & Male & Teacher \\
\hline
\end{tabular}

Following what Denzin (1978) refers to as "inspection", I began to question preliminary findings that seemed to have some range and power by both identifying disconfirming evidence and setting it against the existing literature. This allowed me to test alternative explanations and ascertain what emerging ideas seemed well elaborated and what seemed incomplete. I used the themes that emerged from this process to develop a coding scheme. This prompted the second step to analysis which was more deductive in approach 
and involved using the created scheme to formally code transcribed interviews, classroom observations, field notes and artefacts. During this process, I was required to revise and at times expand the coding scheme to better reflect the nuances of the data.

\section{A note on language}

As will be evident in the subsequent sections, both Spanish and English were used throughout the study. During the data collection process, I made a concerted effort to conduct interviews in the language of choice of my participants. I prefaced all interviews by asking interviewees what language they would feel most comfortable in. All interviews were conducted in Spanish, including a staff interview with the school's English teacher. I was therefore required to translate both interview transcripts and many parts of my field notes in order to make them available to an English-speaking audience. Translations, however, are never a simple or objective process. As Simon (1996) argues, solutions to the many dilemmas that may emerge when translating are never found in dictionaries. When translating, one must "constantly make decisions about the cultural meanings which language carries and evaluate the degree to which the two different worlds [one inhabits] are 'the same' (p. 137). The process of translating, therefore, entails not only the transference of meaning from one language to another, but the production of a whole new understanding of a text (Temple \& Young, 2004). As a result, I decided to keep all quotations in their original form providing my own translations as footnotes. This decision was motivated by a personal effort to preserve interviewee voices in their original form - untampered. It was also a means of promoting some form of transparency, providing bilingual readers a glimpse into my own meaning-making process.

\section{Setting}

The research took place in Unidad Educativa Carlos Tobar ${ }^{3}$ (UECT), a low-income public school located in a large urban center. For much of its history the school was widely considered one the country's premier educational institutions. Its students consistently outperformed their public and private school counterparts in national examinations and competitions. The school's prestige was further iterated by the numerous accomplishments of its alumni, who can still be found in high-ranking positions in both industry and government. While still highly regarded, over the last 10 years the quality of the school's educational provisions has significantly deteriorated.

The school's decline is widely viewed as being a byproduct of the 2008 constitution. Prior to the 2008 constitution, UECT was classified as an experimental school, allowing it to implement its own curriculum and establish its own hiring and admissions processes. As a result of this autonomy, the school attracted and admitted only the highest performing students of the city. In an effort to standardize public education throughout the country, the 2008 constitution and the proceeding 2011 Ley Orgánica de Educacion Intercultural modified UECT's experimental status, requiring it to follow the same operating norms as other public schools. This included implementing the state mandated curriculum known as the Bachillerato General Unificado (BGU), following the hiring and labor requirements determined by the Ministry of Education, and eliminating all prerequisites for admissions which previously included an entrance exam.

The changes first spurred by the 2008 constitution are not, however, the sole cause of the school's decline. Over the last years the school has experienced a slew of internal issues

\footnotetext{
${ }^{3}$ Pseudonym
} 
which include incidences of sexual assault, academic irregularities, and administrative instability. Within a four-year period, for instance, the school had 5 different deans and 7 different vice-deans. Despite the ongoing internal turmoil, the school is still widely portrayed as a high quality and prestigious public school, evidenced by the endless lines of parents outside the school's gates patiently waiting to place their child's name in the upcoming admissions lottery. Contributing to UECT unwavering prestige is the fact that it was one of the first public schools to include the DP in its curricular offerings. Many attribute the schools' early success with the DP as being an important reason for the rapid expansion of the Inserción de Bachillerato Internacional en colegios fiscales del Ecuador initiative. While the school's association with the IB is a source of distinction, it has also inadvertently created tensions within the school, as will be discussed in the subsequent section.

\section{Findings}

Every morning at approximately 6:45 a.m., students from UECT will walk through the main gate, cross a small parking lot and enter the school building. At 7:00 a.m. a siren will ring, indicating the start of the first period. Upon hearing the siren, students will leave the main open patio found at the center of the school and quickly run to their respective classrooms. Students enrolled in the state-mandated national curriculum known as the BGU will head to the first and second floor, where the majority of the school's classrooms can be found. IB students, on the other hand, will head to the smaller third floor which consists of five classrooms, a computer lab and an administrative office. For the remainder of the day, IB students will remain separated from their non-IB peers. Not only are IB classrooms physically removed, but due to the larger amount of coursework and the greater demands of the DP, IB students are required to follow a distinct school schedule which includes a later dismissal and smaller breaks.

The exacting requirements of the DP are evident in the bleary-eyes of the students as they make way to the $3^{\text {rd }}$ floor for their first period classes. In addition to a longer school day, many IB students are required to enroll in extra-curricular English classes in order to meet the language requirements of the program. As one student explained, most of us have English classes after school up to 6. A lot of us only get home at 8 or 9 at night. And then we have to do homework, so we end up going to sleep very late. The strenuous schedule did not seem, however, to discourage students from applying to the program. Every year approximately 100 students will take part of a semester long application process, which includes writing a letter of intent, obtaining teacher recommendations, taking an entrance exam, and being interviewed by the school's IB coordinator. Given that the government sponsors all fees associated with being an IB student, the school is required to place a hard cap on how many applicants are accepted to the program. As a result, only 50 new students are accepted to the program each year.

Although in high demand, enrollment in the DP does include some significant drawbacks. As part of an ongoing policy disarticulation, the diploma conferred by the IB is not recognized as a valid credential for admissions to local universities. When discussing their motivation to join the program, students identified the IB's smaller class sizes, the internationally-focused curriculum, and the desire for a personal challenge as being important reasons. Luis Romero, for instance, described his motivation as being mi motivación fue superarme, y por los conocimientos también ${ }^{4}$.

While all important reasons, IB students almost unanimously discussed the opportunities the program could provide in institutions abroad as being the main motivating

\footnotetext{
${ }^{4}$ My motivation was to grow as a person and for the knowledge as well.
} 
factor. Andrea Macías noted mis compañeros tienen la mentalidad de salir del país, estudiar en Rusia, España, Estados Unidos, quiero decir en otros países. $\Upsilon$ la mayoría que están en el BI tienen como objetivo ingresar a universidades en otros paises. Even though the prospect of pursuing higher education abroad was appealing, students limited financial resources meant that very few would actually have the opportunity to leave. Yet the possibility - however slim - proved to be the main motivation to first enroll and later remain in the program.

In addition to being in high demand amongst the student body, the IB conferred a significant amount of prestige to the school. Remarks were often made comparing the educational provisions at UECT with those of renowned schools around the world, especially in the United States in Europe. A recently published news article about the IB, for instance, stated ¿Qué tienen en común [los] colegios públicos de Ecuador con el prestigioso Instituto Le Rosey de Suiza...Aunque a primera vista no haya muchas similaridades, en ambos casos se ofrece el mismo programa de enseñanza, el Bachillerato Internacional ${ }^{6}$ (Sputnik, 2018). Although a source of pride, the clear boundaries between IB and non-IB students was also viewed as a cause of concern. Fernando Gonzalez, the school's interim dean, argued that the separation of the two curricular tracks had significantly disrupted the school's sense of identity. He stated:

Hay una dicotomía ahi en cuanto... el bachillerato internacional de hecho es diferente al bachillerato nacional. Pero eso genera dentro de la institución como una brecha, como una división, una separación entre esos dos bachilleratos, el nacional y el internacional. $\Upsilon$ eso ha golpeado a la identidad de la institución, ¿̇verdad? Entonces en este momento ya no existe más [la Unidad Educativa Carlos Tobar], lo que existe ahora es una unidad educativa que tiene este tipo de oferta de servicio ${ }^{7}$.

The school dichotomy spurred by the presence of the IB was acknowledged by students from both tracks. Students enrolled in the national curriculum often felt they weren't as highly regarded by the school's teachers and administrative staff. Conversely, the added pressures of being in the IB made many students feel excluded from the activities and social events sponsored by the school. As Julia Arroyo, an IB student, explained: en el colegio mismo, había reuniones o así, y sacaban a toda la generación, menos al BI, porque "BI tienen que estar en clases". Pero eran programas de inclusión o cosas así, entonces nosotros nos sentíamos excluidos.

The perceived differences between the two curricular tracks led to some palpable tensions amongst the school's students. The distinction associated with the IB was often internalized by the student body, routinely leading to offhand comments that reflected feelings of superiority amongst IB students. Macarena Carrillo, an IB student, noted that

\footnotetext{
${ }^{5}$ My classmates have the mentality to leave the country, to study in Russia, Spain, United States, meaning in a different country. And most of those who are in the IB have the objective of being admitted to universities outside of the country.

6 What do Ecuadorian public schools have in common with the prestigious Instituto Le Rosey in Switzerland... While at first glance there aren't many similarities, in both cases they offer the same educational programs, the International Baccalaureate

7 There is a dichotomy in terms of...the International Baccalaureate is in fact different from the national baccalaureate. But within the institution this creates a gap, like a division, a separation between both baccalaureates, the national and the international. And this has rocked the identity of the institution, right? So, at this moment there is no longer the Unidad Educativa Carlos Tobar, what exists is an educational institution which provides these types of services.

${ }^{8}$ Even in the school, there were meetings which they would take the whole grade level except the IB, because "IB has to be in class". But these were programs of inclusion or something like that, so we felt excluded.
} 
these sentiments exacted a significant strain on the relationship between IB and non-IB students. She claimed:

La connotación del término "internacional" cambia demasiado al bachillerato general unificado. Entonces ahi muchas de las veces se creen mejores que los otros estudiantes limitando las capacidades que ellos también tienen, porque no quiere decir que porque estés en BI seas mejor que los de BGU, no. $\Upsilon$ también porque el hecho de creerse, a los otros estudiantes les molesta que se crean lo mejor entonces ahi ya se crea una discordancia total.

Feelings of superiority coupled with differing course schedules compelled Maria Espinosa, a current teacher, to conclude that upon enrolling in the program, IB students inevitably cut social ties with their peers. She stated, en el BI se han visto en años anteriores que rompe sus lasos con sus amigos, ya no se llevan, ya no se conocen, ya no... Esa es, esa es la vida del BI, rompe lasos ${ }^{10}$.

Although students bemoaned the severing of social ties, they often engaged with practices and activities that ultimately helped exacerbated the tension between IB and nonIB students. This was perhaps best exemplified by an incident involving the creation of the senior class' sweatshirts. Every year the student council is responsible for designing and raising funds for the purchase of a sweatshirts for the entire senior class. During the beginning of the academic year a group of IB students along with their parents petitioned for the creation of a distinctive sweatshirt for students enrolled in the program. Fernando Gonzalez rejected the petition stating, yo les dije a los padres que yo me negaba a dar un visto bueno para que llegaran estas chompas mientras que no se unan a los de Bachillerato Nacional. $\Upsilon$ así fue. No les acepte ${ }^{11}$. While the proposal was not accepted, the desire for distinction reflects that the ongoing separation between both curricular tracks is structurally imposed, but continuously reaffirmed by the attitudes and behaviors of the student body.

Similar tensions were found amongst the teaching staff. For many years the school maintained a policy that only the most experienced and accomplished teachers were given exclusive appointments in the IB program. According to Eduardo Alarcon, the IB coordinator, this created problematic dynamics amongst teachers. He stated, habia unos roces tremendos. El BI es una isla, una isla total...Muchos, muchos de los profesores no querían unirse o no querian participar en nada de lo del $B G U^{\prime 2}$. In an effort to diminish the existing friction amongst the teaching staff, the school decided to revoke the aforementioned policy thus requiring all IB teachers to also teach classes in the BGU.

While the new policy did improve relations amongst the teaching staff, it also generated some new forms of dissatisfaction. The large class-sizes and rigid curriculum of the BGU frustrated many of the teachers who had grown accustomed to the flexibility and

\footnotetext{
9 The connotation of the term "international" changes a lot the BGU. Therefore, it causes many times IB students to think they are better than the other students, limiting the potential that these other students may have. It doesn't mean that because you are in the IB you are better than someone in BGU...no. The fact that they think they are better bothers the other students and this creates a state of complete disharmony [in the school].

${ }^{10}$ In previous years you can see that IB students cut ties with their friends, they don't get along, they no longer know each other, they don't... that's the life of an IB student, of cutting ties.

${ }^{11}$ I told the parents that I refused to give my approval for these sweatshirts to arrive if they didn't join with those in the BGU. And that's how it was. I didn't accept.

12 There used to be a tremendous amount of friction. The IB is an island, a total island. Many of the teachers did not want to join or want to participate in anything that had to do with the BGU
} 
intimacy of the IB. Francisco Reyes, one of the longest tenured teachers of the school, highlighted this frustration when he stated la malla curricular del BGU es extenuante y mal, mal planteada. $\Upsilon$ bajar, bueno bajar digo porque nosotros estamos acá arriba y los cursos estos están allá. Es un sofocamiento, a mi me cansóts. Many teachers voiced their dissatisfaction with teaching in the BGU, often portraying it as an inconvenience while also describing the students as unmotivated.

Teachers' frustration with both the BGU curriculum and students had direct implications for classroom instruction. Not only did the student-teacher relationship differ, but classes were far more likely to be cancelled in the BGU. Comparing his experiences in both programs, José Mosquera noted, no sé, yo sentía que como que BGU, como que, si nos enseñaban las materias, pero a veces como que mucho quemeimportismo de los maestros. Entonces teníamos a veces todo un día libre. Veníamos al colegio por nada, literal ${ }^{14}$. While hard to ascertain, it is safe to assume that the selection process implemented by the IB, coupled with teachers' frustration with the BGU inevitably led to significant differences in attainment between students from both curricular tracks. Not only did these differences exist, but they were also publicized during the end of year award ceremony. During these ceremonies almost all awards recognizing academic achievement were given to IB students. As Fernando Gonzalez explained:

También hay engendrado malestar con las calificaciones. Por ejemplo, aquí en el Ecuador, en [la Unidad Educativa Carlos Tobar] se dan medallas a los 10 mejores egresados en cada promoción. $\Upsilon$ siempre ha abarcado a los de Bachillerato Internacional como los mejores estudiantes o cuando hacen la proclamación de abanderados y escoltas la mayoría son del Bachillerato Internacional. Entonces todo eso genera, es como que bien como estigmatización eso, ¿̇no?

When walking through the hallways and engaging in informal conversation with students I was introduced to the saying te bajas al BGU y te subes al $B I^{16}$. After hearing the saying numerous times, I decided to ask the history teacher whether it had some deeper meaning. Juan José Sánchez explained el BI está en el tercer piso y supuestamente es la crema y nata

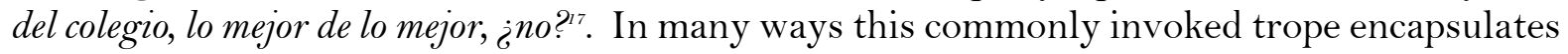
the sentiments and perceptions previously discussed. It refers to both the physical location of the IB and the perception of exclusivity and distinction associated to the program. It also implies that those enrolled in the IB are experiencing some form of upward trajectory, while those in the BGU are heading in the opposite direction.

\footnotetext{
${ }^{13}$ The BGU's curriculum is exhausting and poorly planned. And to go down, well down because we are up here, and those classes are down there. Its, its suffocating, I am tired of it.

${ }^{14}$ I don't know, I felt like in BGU, like, yes, they taught us the course material but sometime the teachers seemed very indifferent. So, we sometimes had the whole day free. We would come to school to do nothing, literally.

15 There is engendered discomfort with the grades. For example, here in Ecuador, in UECT we give medals to the 10 best students of each year. And it always includes the International Baccalaureate as the best students or when they make the proclamation of flag bearers and escorts the majority are from the International Baccalaureate. So this generates, it's like a stigmatization this, right?

${ }^{16}$ You go down to BGU and you go up to the IB

${ }^{17}$ The IB is on the third floor and supposedly it is the cream of the crop of the school, the best of the best, right?
} 


\section{Discussion}

Inclusion in education is often associated with efforts aimed on ameliorating the learning conditions of students with disabilities. As a result, the concept is often mistakenly reduced to the "movement of students in special education from separate and isolated facilities and classroom into neighborhood schools and general education classrooms" (Artiles, Kozleski, Dorn, \& Christensen, 2006, p. 67). Recent interpretations have attempted to expand the concept to consider how school cultures can be transformed in an effort to maximize participation and achievement of all students (Booth \& Ainscow, 2000; Schuelka \& Johnstone, 2012). An emphasis on both "transformation" and "all students" has two longstanding implications for the concept. First it creates a significant point of departure from policies and approaches that emphasize the importance of integration without considering the necessary support mechanism needed to enable full participation. Second, it broadens the concept allowing it to encompass a wide variety of experiences in addition to those related to disability (Bittencourt, Johnstone, Adjei \& Seithers, 2019; Vitello \& Mithaug, 1998).

The broadening of inclusion in education allows initiatives such as the Insercion de Bachillerato Internacional en colegios fiscales del Ecuador to fall within the concept's scope of consideration. Of particular interest is the intent underlying the policy which includes both a short- and long-term goal. In the short-term the policy endeavors on providing a select group of low-income students' access to a prestigious and academically rigorous curriculum that historically was only to the avail of affluent students enrolled in elite private institutions. In the long-term, the policy aims on instilling enduring changes to the country's public educational system which would have implications for all students. Together, these stated goals allow the policy to align with a larger state project aimed on equalizing social opportunity by disrupting existing patterns of social reproduction that are argued as being the vestiges of both colonialism and recent neoliberal approaches to governance.

At its core, the Inserción de Bachillerato Internacional en colegios fiscales del Ecuador initiative is an approach to social inclusion. What this study has attempted to highlight is that the outcome of a policy underlined by a logic of inclusion can be uncertain and at times even counterproductive. As was common in UECT, the presence of the IB created unanticipated challenges ranging from tensions amongst students, teachers' indifference to BGU classes and even a general stigmatization of students who were not enrolled in the DP. As Fernando Gonzalez clearly articulated, the IB has disrupted social cohesion and ultimately created a dichotomized school. Although unintended, the policy has reconfigured the school creating conditions which could potentially compromise the learning and successful achievement of some members of the student body.

By showcasing these potentially detrimental outcomes, I am not suggesting that the policy should be discredited. As has already been highlighted in multiple studies, policies aiming on instilling significant change may influence individuals and educational institutions in very different ways (see Yilmaz \& Kiliçoğlu, 2013). The findings from this study must therefore be interpreted with caution and be considered unique to its specific context. While the impulse for generalization must be tempered, the findings do signal to the potential risks of conceiving of inclusion as a standalone action which attempts to include vulnerable groups into existing educational arrangements (Ainscow, 2005). Without the necessary follow-up mechanisms, schools may be confronted with uncertain outcomes which can, as demonstrated in this study, be damaging.

Although some forms of follow-up existed in UECT, they were mostly limited to isolated and reactive attempts by concerned individuals seeking to attenuate the growing tensions amongst both teachers and students. This is exemplified by the decision to cancel 
exclusive teaching appointments to the IB once it became evident that the policy created friction amongst the teaching staff. To be effective, however, follow-up needs to be systematic, proactive and part of a school-wide effort.

Instilling these types of mechanisms requires a shared understanding that inclusion is a never-ending process, one that demands consistent reevaluation and adaptation. As Ainscow, Booth and Dyson (2006) argue, it requires the recognition that "an inclusive school is one that is on the move rather than one that has reached a perfect state" (p. 25). Viewing inclusion as a process transforms the concept from a program model to a mode of thinking about education. Embedding this understanding into the fabric of a school's culture is imperative and requires a concerted effort spearhead by effective leadership (Zollers, Ramanathan, \& Yu, 1999). In the absence of congruency between an inclusive initiative and school culture even successful programs may experience diminished benefits over time (McCart, Sailor, Bezdek, \& Satter, 2014). Or more alarming, as is the case of UECT, it can lead to outcomes that are counterproductive to an initiative's intent.

\section{Conclusion}

The Inserción de Bachillerato Internacional en colegios fiscales del Ecuador initiative was conceived and implemented as a means of addressing pervading social inequality. Aligned with a larger state project, the initiative was envisioned as being an effective means of promoting long-lasting change to its public educational system. Although framed as a remarkable success, the initiative has also been subject of pointed critiques especially by the country's highly politicized teacher's union. The existence of repudiation has not, however, discouraged the Ministry of Education which by all indications remains firmly committed to bringing the DP into as many of the country's public secondary schools as possible.

Consistent with what has been coined as the "cultural turn" to social reproduction, this study employed an idiographic approach to research focusing on the cultural arrangements and understandings that emerge when a policy is contextualized in a specific locale. Findings revealed that contrary to the goal of promoting social inclusion, the presence of the IB created numerous tensions at the school-level that could potentially undermine the initiative's intent. Arguably of greatest importance was that once implemented, the initiative stigmatized students who either did not apply or were not accepted to the program. This stigma was not only internalized by the student body, but also prompted an indifference amongst teachers regarding their non-IB students. Ultimately, while the policy did "include" low-income students by providing access to the credentials and educational experiences historically restricted to elite private schools, it also created new and unanticipated forms of exclusion.

The emerging tensions are a direct result of the specific contextual arrangements of UECT. Although findings are unique to the site of study, they do indicate a general trend in inclusive policies which has been previously highlighted in the existing literature. This includes the importance of a shared vision of inclusion not as a standalone program, but as an endless process aimed on maximizing participation and achievement for all students. Only through this shared vision can the necessary support mechanisms be established that can proactively anticipate the potentially detrimental outcomes of a policy once it is contextualized in a school or even in a specific classroom.

Establishing a shared vision which is cemented in the school's culture requires a concerted effort by all stakeholders, but that is spearheaded by effective school leaders. As Zollers, Ramanathan and $\mathrm{Yu}$ (1999) argue, inclusive reforms that fail to consider the characteristics of a school's culture are bound to be unsustainable. Instead, an inclusive 
program must be undergirded by a school culture whose values and vision are conducive to the initiative's intent. This is perhaps the most important lesson for UECT. The school's ongoing struggles triggered in part by administrative instability prohibit the possibility of establishing a shared vision about inclusion. The hope is that once leadership becomes stable, the school can begin to reconfigure in a manner which is conducive to the values and intent central to a policy which strives for social inclusion.

\section{References}

Ainscow, M. (2005). Developing inclusive education systems: What are the levers for change. Journal of Educational Change, 6(2), 109-124.

Ainscow, M., Booth, T., \& Dyson, A. (2006). Improving schools, developing inclusion. New York: Routledge.

Albuja, A. A. (2016). Hacia una sociedad educadora: Propuesta para el debate. Quito: Minga Libre. Retrieved from https://www.grupofaro.org/content/hacia-una-sociedadeducadora-propuestas-para-el-debate

Althusser, L. (2001). Lenin and philosophy and other essays. New York: Monthly Review Press.

Anyon, J. (1980). Social class and the hidden curriculum of work. Journal of Education, 162(1), 1-11.

Arsel, M. (2012). Between Marx and markets? The state, the left turn and nature in Ecuador. Tijdschrift voor Economishe en Sociale Geografie, 103(2), 150-163.

Artiles, A. J., Kozleski, E. B., Dorn, S., \& Christensen, C. (2006). Learning in inclusive education research: Re-mediating theory and methods with a transformative agenda. Review of Research in Education, 30(1), 65-108.

Barnett, E., Tokuhama-Espinos, T., Rivera, M., Montero, L. A., \& Palacios, T. P. (2013). Research on the implementation of the Diploma Programme in Ecuadros' state schools. New York City: National Center for Restructuring Education, Schools, and Training.

Bittencourt, T., Johnstone, C., Adjei, M., \& Seithers, L. (2019). "We see the world different now": Remapping assumptions about international student adaptation. Journal of Studies in International Education, 1-16. doi:10.1177/1028315319861366

Booth, T., \& Ainscow, M. (2000). Index for inclusion: Developing learning and participation in schools. Bristol, England: Centre for Studies on Inclusive Education.

Bourdieu, P. (1979). Distinctions. A social critique of the judgment of taste. Cambridge: Harvard University Press.

Bourdieu, P. (1987). What makes a social class? On the theoretical and practical existence of groups. Berkley Journal of Sociology, 32, 1-17.

Bowles, S., \& Gintis, H. (1976). Schooling in capitalist America: Educational reform and the contradictions of economic life. New York: Basic Books Inc.

Brantlinger, E. (2003). Dividing classes: How the middle class negotiates and rationalizes school advantage. New York: Routledge.

Bunnell, T. (2011). The International Baccalaureate: Its growth and complexity of challenge. In R. Bates, Schooling internationally: Globalisation, internationalisation and the future for international schools (pp. 165-181). Abingdon: Routledge.

Calarco, J. M. (2018). Negotiating opportunities: How the middle class secures advantages in school. Oxford: Oxford University Press.

Chaney, D. (1994). The cultural turn: Scene-setting essays on contemporary cultural history. London: Routledge.

Charmaz, K. (2006). Constructing grounded theory: A practical guide through qualitative analysis. London: SAGE Publications. 
Demerath, P. (2009). Producing success: The culture of personal advancement in an American high school. Chicago: The University of Chicago Press.

Denzin, N. (1978). The research act: A theoretical introduction to sociological methods. New York: McGraw-Hill.

Doherty, C. (2013). Making a point of difference: The glocalised ecology of the International Baccalaureate Diploma in Australian schools. Globalisation, Societies and Education, 11 (3), 379-397.

Espinosa, A. (2013). Acuerdo No. O224-13. Quito: Ministerio de Educacion.

Foley, D. (2010). Learning capitalist culture deep in the heart of Tejas. Philadelphia: University of Pennsylvania Press.

Friedman, H. L. (2013). Playing to win: Raising children in a competitive culture. Los Angeles: University of California Press.

Groenewald, T. (2008). Memos and memoing. In L. Given, The SAGE ecyclopedia of qualitative research methods (pp. 506-507). Thousand Oaks, CA: Sage.

Hill, I. (2002). The history of international education: An International Baccalaureate perspective. In M. Hayden, J. Thompson, \& G. Walker, International education in practice: Dimensions for national and international schools (pp. 18-29). New York: Routledge.

IBO. (2016, March). Guide to school authorization: Diploma Programme. Retrieved from International Baccalaureate Organization:

http://www.ibo.org/globalassets/publications/become-an-ib-school/dp-guideschool-authorization-en.pdf

IBO. (2017, May 30). Fees for authorized schools. Retrieved from International Baccalaureate: http://www.ibo.org/become-an-ib-school/fees-and-services/fees-for-authorizedschools/

Isch, E. L. (2011). Las actuales propuestas y desafíos en educación: El caso Ecuatoriano. Educação É Sociedade, 32(115), 373-391.

Khan, S. R. (201 1). Privilege: The making of an adolescent elite at St. Paul's school. Princeton: Princeton University Press.

Lareau, A. (2011). Unequal childhoods: Class, race, and family life. Berkley: University of California Press.

McCart, A., Sailor, W., Bezdek, J., \& Satter, A. (2014). A framework for inclusive educational delivery systems. Inclusion, 2(4), 252-264.

Merriam, S. B., \& Tisdell, E. J. (2016). Qualitative research: A guide to design and implementation (4th ed.). San Francisco: Jossey-Bass.

Ministerio de Educación . (2017, June 1). Meta del Compromiso Presidencial. Retrieved from Ministerio de Educación : https://educacion.gob.ec/meta-del-compromisopresidencial/

Paladines, C. (2015). Perspectivas de cambio en la educación básica y en el Bachillerato. Ecuador 2007:2013. PRAXIS, 19(3), 13-31.

Resnik, J. (2012). The denationalization of education and the expansion of the International Baccalaureate. Comparative Education Review, 56(2), 248-269.

Resnik, J. (2014). Who gets the best teachers? The incorporation of the IB program into public high schools and its impact on teacher labor market in Ecuador. In R. Arber, J. Blackmore, \& A. Vongalis-Macrow, Mobile teachers, teacher identity and international schooling (pp. 95-119). Rotterdam: Sense Publishers. 
Saavedra, A. R., Lavore, E., \& Georgina, F.-I. (2016). The International Baccalaureate Diploma Programme in Mexico as preparation for higher education. Compare: $A$ Journal of Comparative and International Education, 46(3), 344-368.

Schneider, B. R., Estarellas, P. C., \& Bruns, B. (2017). The politics of transforming education in Ecuador: Confrontation and continuity, 2006-17. Oxford: Rise Programme. Retrieved from http://www.riseprogramme.org/sites/www.riseprogramme.org/files/Bruns\%20Th e\%20politics\%20of\%20transforming\%20education\%20in\%20Ecuador\%206.1 1.2017. pdf

Schuelka, M., \& Johnstone, C. J. (2012). Global trends in meeting the educational rights of children with disabilities: From international institutions to local responses. Reconsidering Development, 2(2), 1-14.

Simon, S. (1996). Gender in translation: Cultural identity and the politics of transmission. London: Routledge.

Sputnik. (2018, January 13). Conoce la ambiciosa revolución educativa que lleva adelante Ecuador. Ecuador. Retrieved from https://mundo.sputniknews.com/cultura/201801131075398236-bachilleratointernacional-ecuador/

Tamayo, M. L. (2014). La educación en el Ecuador 1980-2007. Revista Iberoamericano de Educación, 65(1), 1-15.

Tarc, P. (2009). Global dreams, enduring tensions: International Baccalureate in a changing world. New York: Peter Lang Publishing.

Temple, B., \& Young, A. (2004). Qualitative research and traslation dilemmas. Qualitative Research, 4(2), 161-178.

Terán, R. N. (2015). Educación, cambio institucional y equidad. Boletín Informativo Spondylus, 1-12.

Vitello, S., \& Mithaug, D. (1998). Inclusive schooling: National and international perspectives. Mahwah, NJ: Lawrence Erlbaum.

Willis, P. (1977). Learning to labor: How working class kids get working class jobs. New York: Columbia University Press.

Yemini, M., \& Dvir, Y. (2016). International Baccalaureate as a litmus test revealing conflicting values and power relations in the Israeli education system. Discourse: Studies in the Cultural Politics of Education, $37(2), 310-323$.

Yilmaz, D., \& Kiliçoğlu, G. (2013). Resistance to change and ways of reducing resistance in educational organizations. European Journal of Research on Education, 1(1), 14-21.

Zollers, N., Ramanathan, A. K., \& Yu, M. (1999). The relationship between school culture and inclusion: How an inclusive culture supports inclusive education. International Journal of Qualitative Studies in Education, 12(2), 151-174.

\section{About the Author}

Tiago Bittencourt is a $\mathrm{PhD}$ candidate in Comparative and International Development Education at the University of Minnesota - Twin Cities. Among his research interests are the internationalization of education, educational policy borrowing, social reproduction theory and issues of class culture. 